\title{
Potential of bigleaf lupine for building and sustaining Osmia lignaria populations for pollination of apple
}

\author{
Cory S. Sheffield ${ }^{1,2}$ \\ Department of Environmental Biology, University of Guelph, Guelph, Ontario, Canada N1G 2W1, \\ and Agriculture and Agri-Food Canada, 32 Main Street, Kentville, Nova Scotia, Canada B4N 1J5
}

Sue M. Westby, ${ }^{3}$ Robert F. Smith ${ }^{3}$

Agriculture and Agri-Food Canada, 32 Main Street, Kentville, Nova Scotia, Canada B4N 1J5

Peter G. Kevan

Department of Environmental Biology, University of Guelph, Guelph, Ontario, Canada N1G 2W1

\begin{abstract}
Bees of the genus Osmia Panzer (Hymenoptera: Megachilidae) are among the contenders to replace honey bees, Apis mellifera L. (Apidae), for pollinating tree-fruit crops. One species, Osmia lignaria Say, has shown great potential in western North America and was recently introduced into Nova Scotia for evaluation as a pollinator of apple, Malus Mill. (Rosaceae). A major component of that study was to develop management options for O. lignaria, including methods of sustaining nesting females following crop flowering to maximize population recovery for pollination in subsequent seasons. The objective of this study was to evaluate bigleaf lupine, Lupinus polyphyllus Lindl. (Fabaceae), as a secondary food plant for nesting female $O$. lignaria by investigating nesting activity, pollen-use patterns, and fecundity. During 2002-2003, female $O$. lignaria collected high proportions of apple pollen $(>70 \%)$ during mid and late flowering; after then, most pollen (>90\%) was collected from bigleaf lupine. The flowering period of lupine in Nova Scotia (late May to early July) slightly overlapped that of apple, so there was no scarcity of pollen resources during the life-span of $O$. lignaria. Most nests typically showed high levels $(\leq 200 \%)$ of population growth, but recorded levels varied among nest types and locations. In 2004, nests closer to lupine plots exhibited significantly greater population recovery than nests located farther away (i.e., approximately $600 \mathrm{~m}$ ). Bigleaf lupine is a suitable plant species for meeting the pollen requirements of nesting populations of $O$. lignaria following apple flowering, thus promoting the recovery of populations to meet apple pollination requirements in subsequent seasons.
\end{abstract}

Résumé-Les abeilles du genre Osmia Panzer (Hymenoptera: Megachilidae) font partie des candidats pour remplacer les abeilles domestiques, Apis mellifera L. (Apidae) pour la pollinisation des cultures d'arbres fruitiers. Une espèce, Osmia lignaria Say, qui montre un potentiel intéressant dans l'ouest de l'Amérique du Nord, a été introduite récemment en Nouvelle-Écosse pour être évaluée comme pollinisateur du pommier, Malus pumila Mill. (Rosaceae). Une partie importante de l'étude consistait en la mise au point de méthodes de gestion d' $O$. lignaria, en particulier des méthodes pour le maintien des femelles nidificatrices après la floraison des pommiers afin de maximiser la récupération de la population en vue de la pollinisation durant les saisons suivantes. L'objectif de ce travail est d'évaluer le lupin polyphylle, Lupinus polyphyllus Lindl. (Fabaceae), comme plante alimentaire secondaire des femelles nidificatrices d'O. lignaria, par des études de l'activité de nidification, des patrons d'utilisation des pollens et de la fécondité. En 2002-2003, les femelles d'O. lignaria ont récolté de fortes proportions de pollen de pommier $(>70 \%)$ durant les périodes moyenne et tardive de la floraison; plus tard, la majorité du pollen récolté ( $>90 \%)$ provenait du lupin polyphylle. La période de floraison du lupin en Nouvelle-Écosse (de la fin de mai au début de juillet) chevauche un peu celle du pommier et il n'y a pas de pénurie de

Received 12 December 2007. Accepted 11 July 2008.

${ }^{1}$ Present address: Department of Biology, York University, 4700 Keele Street, Toronto, Ontario, Canada M3J 1 P3.

${ }^{2}$ Corresponding author (e-mail: corys@yorku.ca).

${ }^{3}$ Retired. 
ressources polliniques durant la durée de la vie d'O. lignaria. La plupart des nids affichent généralement des taux élevés $(\leq 200 \%)$ de croissance de population, mais les taux sont variables en fonction des types de nids et des sites. En 2004, les nids plus près des parcelles de lupins avait un taux de récupération significativement supérieur à celui des nids situés plus loin (c'est-à-dire environ $600 \mathrm{~m}$ ). Le lupin polyphylle est donc une espèce de plante appropriée pour satisfaire les besoins en pollen des populations nidificatrices d'O. lignaria après la floraison du pommier; il favorise la récupération de la population pour assurer la pollinisation des pommiers durant les années suivantes.

[Traduit par la Rédaction]

\section{Introduction}

Humans rely strongly upon the European honey bee, Apis mellifera L. (Hymenoptera: Apidae: Apinae), for pollinating many crops (Free 1993). The capacity for highly effective communication among nestmates of this eusocial bee promotes quick discovery and subsequent exploitation of food resources (Lindauer 1967; von Frisch 1967). In addition, commercial honey bee colonies contain high numbers of foragers in portable hives that can be moved between crops as pollination services are required (DeGrandi-Hoffman 1987). Usually, honey bee colonies are placed in crop systems only when needed; this practice promotes fruit production and reduces the risk of pesticide exposure.

Honey bees are not the most efficient pollinators for many crops (Free 1993), and in North America, interest in the basic biology of non-Apis bee species and the development of promising species for crop pollination have increased since the 1940s (Torchio 1990; Batra 2001; Strickler and Cane 2003). More recently, the need for this research has increased because of a higher incidence of honey bee diseases and pests (DeGrandi-Hoffman 2003; Kevan 2003) and, more recently still, colony-collapse disorder (Cox-Foster et al. 2007). Despite promising results with some species (Bohart 1972; Parker et al. 1987; Strickler and Cane 2003), very few of the estimated 3000-4000 non-Apis bee species in North America have been developed for commercial pollination.

Successful management of non-Apis bees is largely limited to species that nest in "manageable" material such as trap-nests, primarily the cavity-nesting members of the Megachilidae (Torchio 2003; Sheffield et al. 2008a). Although these species are excellent pollinators of some crops, techniques for managing them differ greatly from those used for honey bees. Honey bee colonies require continuous availability of food resources during periods of colony growth and for overwintering. Most solitary bees live for a month or less (Michener 2007) and are managed annually for pollinating a single crop (Free 1993; Torchio 2003). Thus, solitary bees are often used in settings where the crop flowering period is significantly shorter than the active period of adult bees. In Nova Scotia, for example, flowering of apple (Malus pumila Mill. (Rosaceae)) lasts approximately 10 days (Sheffield 2006). The period of potential food scarcity following apple flowering may reduce fecundity and population recovery of solitary bees within these systems (Williams and Kremen 2007). Solitary bees should be considered a commodity when used as crop pollinators (Stephen 1973), and options for maximizing their fecundity (and their effects on crop productivity) should be explored (Abel and Wilson 1998).

Osmia lignaria Say (Megachilidae) is the most promising North American solitary bee for pollinating tree-fruit crops (Bosch and Kemp 2001; Torchio 2003) and was introduced into Nova Scotia during 2000-2004 for evaluation as an apple pollinator (Sheffield 2006). In that study, options for managing this species in Nova Scotia were investigated, including overwintering (see Sheffield et al. 2008b) and techniques for increasing populations to meet pollination needs in subsequent seasons. In the weeks following apple flowering in 2001, female $O$. lignaria nesting adjacent to a research orchard continued to provision their nests, and more than $90 \%$ of this pollen came from a roadside population of bigleaf lupine, Lupinus polyphyllus Lindl. (Fabaceae) (Sheffield 2006).

The objective of the research reported here was to further evaluate bigleaf lupine as a suitable food plant for building populations of $O$. lignaria following apple flowering in Nova Scotia. Our evaluation was based on evidence of pollen usage, nesting activity, population recovery, and synchrony of flowering periods of the two plant species. 


\section{Materials and methods}

\section{Studies in research orchards in 2002 and 2003}

\section{Study sites}

Two research orchards were used for studies in 2002 and 2003. Site I was a 3 ha orchard on the Sheffield Farm $\left(45^{\circ} 07^{\prime} \mathrm{N}, 64^{\circ} 28^{\prime} \mathrm{W}\right)$ at the Agriculture and Agri-Food Canada substation in Upper Canard, Kings County, Nova Scotia. The orchard consisted of alternating double rows of 'McIntosh' and 'Cortland' apple trees with $6 \mathrm{~m}$ spacing between rows. Rows were arranged in a north-south orientation with $4.5 \mathrm{~m}$ tree spacing. A roadside ditch bordered the south end of the orchard and contained a population of hundreds of naturalized bigleaf lupine plants that had existed for at least 10 years (C.S. Sheffield, pers. obs.). In addition to our pollination research, various pest-management studies (e.g., researching organic, integrated pest management, and integrated fruit production methods) were being conducted in this orchard and it was subject to localized pesticide spraying (i.e., individual or small groups of trees) primarily at the south end of the orchard.

Site II was a 0.3 ha orchard $\left(45^{\circ} 05^{\prime} \mathrm{N}\right.$, $64^{\circ} 28^{\prime} \mathrm{W}$ ) maintained at the Atlantic Food and Horticulture Research Centre in Kentville, Kings County. This site contained scab-resistent 'NovaMac' and 'NovaSpy' apple trees in rows oriented east-west and tree spacing as above. In 2001, two plots of lupines measuring approximately $3 \mathrm{~m} \times 45 \mathrm{~m}$ were established at the south end of the orchard to flower in 2002 and 2003. These plots included wild bigleaf lupine (seeds collected from site I) but contained mainly an ornamental mixture of bigleaf lupines obtained from a commercial seed supplier (Halifax Seed, Halifax, Nova Scotia). No pesticides were used in this orchard during the study.

\section{Flowering phenology}

Flowering phenology of the apple cultivars was determined at site I in 2002-2003 and at site II in 2003. Prior to flowering each year, a limb on each of 20 randomly selected trees (46 trees per row) of each cultivar was tagged and the total number of flower clusters and buds determined (Dafni 1992). Open flowers were counted daily until petal fall.

Owing to the great number of flower buds per plant, lupine flowering phenology was determined differently: the approximate date of the beginning of flowering and estimates of $25 \%$ (bottom $1 / 4$ of raceme), full (middle $1 / 2$ of raceme), and late bloom (top $1 / 4$ of raceme in flower, lower $1 / 4$ with seed set) for the population were recorded on the basis of visual observation. In addition, the date on which $O$. lignaria were first seen collecting pollen from lupines was recorded in 2002 and 2003. Literature accounts of lupine flowering in the province were also examined (Dunn and Gillett 1966; Zinck 1998).

\section{Nesting boxes and bee release rates}

Osmia lignaria used in 2002 were imported into Nova Scotia from Logan, Utah, United States of America (Torchio Enterprises) in the autum of 2001 and overwintered in cold storage at $4{ }^{\circ} \mathrm{C}$ as per recommended wintering methods (see Sheffield et al. 2008b). For 2003, bees were not received until January 2003 because import permits were delayed. January importation creates the potential for fat-body depletion and premature emergence if bees are exposed to relatively high temperatures (Sheffield et al. $2008 b$ ). This shipment of bees was received after a transit period of approximately 1 week (conditions were not recorded) and placed in cold storage at $4{ }^{\circ} \mathrm{C}$.

Throughout the study, attempts were made to balance the numbers of females (but not males) released among nests at each site, as they are the primary pollinators, and population recovery (see below) is based on their fecundity. Male release at each nest was quantified but not balanced among nests, as this would require removing bees from nesting tubes and the number of males released was not expected to have an impact on female nesting success or fecundity.

In 2002, wooden nests (Fig. 1A) and paired "milk carton" (MC) nests (each containing 24 milk cartons; Fig. 1B) were set up approximately 2 weeks prior to flowering (see below) within site I at three distances from the ditch containing lupines: adjacent to the lupines, halfway between the lupines and the woods at the north end of the orchard (approximately $90 \mathrm{~m}$ from the lupines), and adjacent to the north end of the woods (approximately $180 \mathrm{~m}$ from the lupines). At each distance, one wooden nest and two paired MC nests, equally spaced at two rows apart, were placed approximately $1.5 \mathrm{~m}$ above ground level on posts and facing south. In 2003, nine pairs of MC nests were used, with the same arrangement as in 2002. Bee release rates and times for site I for 2002-2003 are 
Fig. 1. (A) Wooden nests used for Osmia lignaria in 2002. (B) Milk carton nests used in 2002-2004.
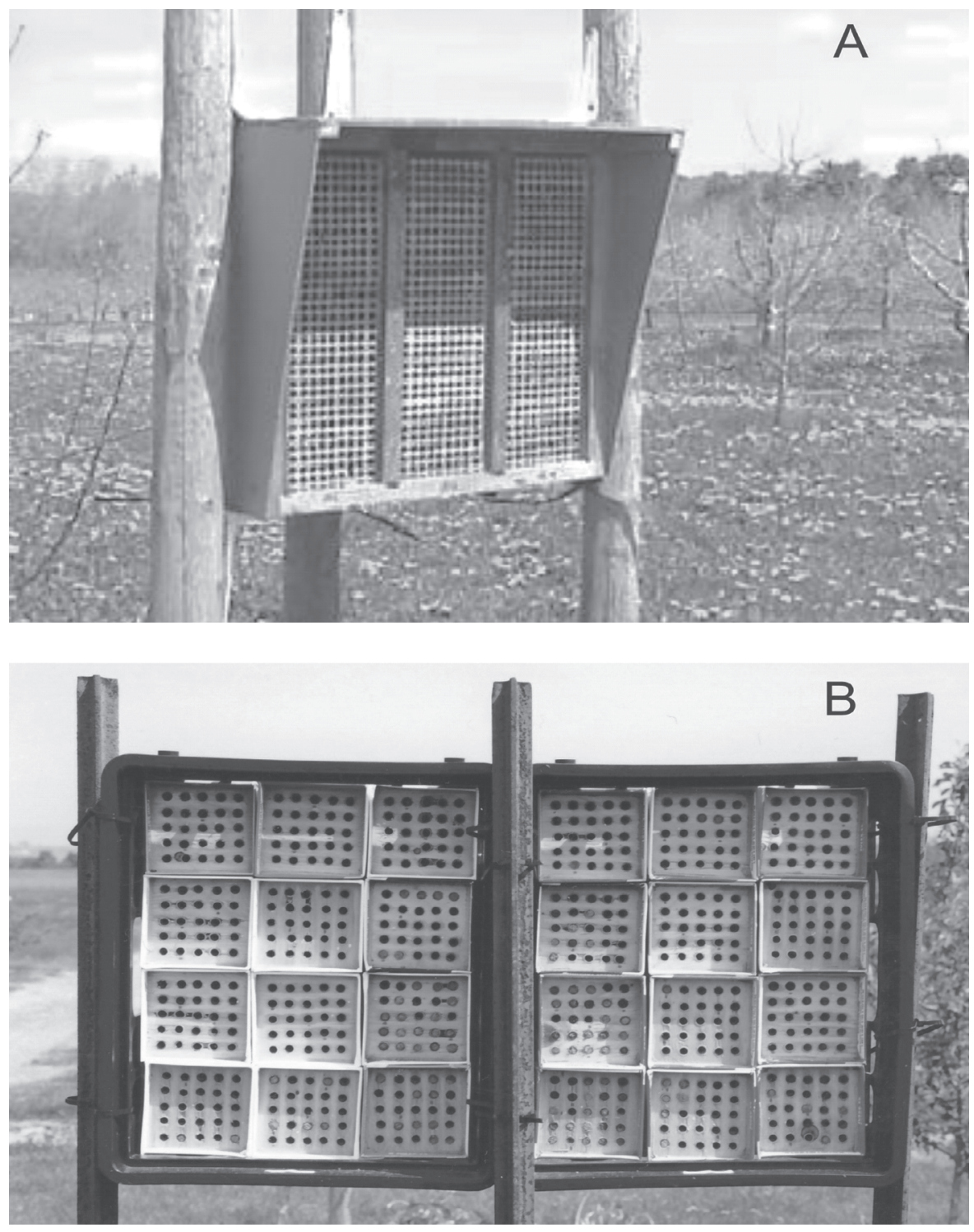

summarized in Table 1. Within a week following each date of release of bees in 2002-2003, the nesting tubes initially containing the released bees were inspected for live bees, then removed and replaced with empty nesting tubes. Non-emerged cocoons of each sex were counted and subtracted from the initial release totals. All recovery in 2002-2003 was analysed using the corrected release rates (see below) summarized in Table 1.

In 2002, three MC nests were placed at the western edge of the orchard at site II, equally spaced at increasing distances from the lupine plots. Bees were released into these nests on 16
May 2002 at the following corrected rates: nest A (adjacent to the lupines), 46 우 우: $77 \sigma^{\pi} \sigma^{\pi}$; nest B (35 m from the lupines), 39 우 우: 67 우 우; and nest C (70 m from the lupines), 45 우우 : $800^{x} \sigma^{x}$. In 2003, six nesting boxes of the same type were used, with three each placed on the east and west sides of the orchard block. On 23 May 2003, each of these nests was provided with the following corrected numbers of bees: nest A, 8 우우 : 10 우우, and nest F, 13 우우 : 42 우우 (adjacent to the lupines); nest $\mathrm{B}, 11$ 우우: 44 우우, and nest E, 11 우우 : 43 우우 (35 $\mathrm{m}$ from the lupines); and nest $\mathrm{C}, 11$ 우우 : 40 우우, and nest $\mathrm{D}, 6$ 우우: 38 우우 (70 $\mathrm{m}$ from the lupines). 
Table 1. Corrected rates of release (see the text for details) of bees on 16 May 2002 and 26 May 2003 at site I for wooden and milk carton (MC) nests adjacent to $(<5 \mathrm{~m}), 90 \mathrm{~m}$ from, and $180 \mathrm{~m}$ from lupine plots.

\begin{tabular}{lccc}
\hline $\begin{array}{l}\text { Year and } \\
\text { nest }\end{array}$ & $\begin{array}{c}\text { Distance } \\
\text { from lupines } \\
(\mathrm{m})\end{array}$ & $\begin{array}{c}\text { No. of } \\
\text { females } \\
\text { released }\end{array}$ & $\begin{array}{c}\text { No. of } \\
\text { males } \\
\text { released }\end{array}$ \\
\hline $\mathbf{2 0 0 2}$ & & & \\
Wooden A & $<5$ & 154 & 260 \\
Wooden B & 90 & 141 & 292 \\
Wooden C & 180 & 168 & 210 \\
MC1 & $<5$ & 37 & 106 \\
MC2 & $<5$ & 39 & 95 \\
MC3 & 90 & 48 & 63 \\
MC4 & 90 & 42 & 69 \\
MC5 & 180 & 38 & 93 \\
MC6 & 180 & 42 & 91 \\
2003 & & & \\
MC1 & $<5$ & 81 & 264 \\
MC2 & $<5$ & 64 & 102 \\
MC3 & $<5$ & 79 & 126 \\
MC4 & 90 & 64 & 111 \\
MC5 & 90 & 57 & 134 \\
MC6 & 90 & 64 & 121 \\
MC7 & 180 & 63 & 146 \\
MC8 & 180 & 63 & 160 \\
MC9 & 180 & 63 & 90 \\
\hline Note & & & \\
\hline
\end{tabular}

Note: A secondary release of additional bees (wooden A, 43 웅, $790^{x} 0^{x}$; wooden B, 38 우, $730^{x} 0^{x}$; wooden C, 41 우, $\left.610^{\pi} 0^{\pi}\right)$ was made on 27 May 2002 and 4 June 2003 (25우 우 and a minimum of $500^{\pi} 0^{\pi}$ at each nest).

\section{Nesting activity and population recovery}

Weekly assessments of nesting activity were conducted in 2002 after sunset at all nests within both orchards, and the number of females in each nesting box was recorded. In addition, the number of capped tunnels was recorded for each nest, providing an indirect measure of recovery. Counts were repeated until no females were observed at the nests. At the end of the flight period, nests were removed from each site and placed in an unheated screened insectary until the wintering stage was reached (October-November). Nesting tubes were then removed from the nesting boxes and split lengthwise to expose the cocoons and determine the number and sex.

In 2002-2003, recovery was compared among distances from the lupines, using corrected release rates. Data for each nest type (wooden and MC) at site I in 2002 were analysed and recovery data for MC nests at the different distances were pooled. Recovery data were compared using $\chi^{2}$ analysis, and expected values $(E)$ for each distance were calculated using $E=\mathrm{CR}_{i} / \mathrm{TCR} \times N$, where $\mathrm{CR}_{i}$ is the corrected number of females released at each distance, TCR is the total corrected number of females released at the site (for each nest type when necessary), and $N$ is the total number of bees produced.

\section{Pollen preferences}

In 2002 and 2003, plant and pollen collections were completed at each study site to help identify pollen sources used by $O$. lignaria during apple and lupine bloom periods. Pollen samples were collected from fresh and dried plants and placed in silicone oil on glass slides. Pollen was also collected from the abdominal scopa of female $O$. lignaria returning to nesting tunnels by capturing them with small aquarium nets and lightly rubbing cotton swabs on the pollen load. Bees were released following pollen collection. Care was taken to ensure that the same bee was not collected twice during the same collection trip by noting which tunnel was visited and by alternating nests during each collection period (especially when nesting activity was slow). Cotton-swab ends were cut and sealed individually in plastic vials and a pollen sample was later mounted in silicone oil on a glass slide. Up to 10 samples were collected from each nesting box depending on flight activity and (or) the number of bees remaining at the nest. Slide-mounted loads were later analysed for pollen type(s) by counting at least 300 pollen grains from randomly selected fields of view. The proportion of pollen type collected was subjected to arcsine transformation and analysed using ANOVA (Zar 1999).

\section{Studies in commercial orchards in 2004}

To determine the effectiveness of lupines in commercial orchard systems, lupine plots were established in 2003 within two orchard systems, in Wolfville $\left(45^{\circ} 04^{\prime} \mathrm{N}, 64^{\circ} 23^{\prime} \mathrm{W}\right)$ and Aylesford $\left(45^{\circ} 02^{\prime} \mathrm{N}, 64^{\circ} 49^{\prime} \mathrm{W}\right)$, each $>20$ ha and containing many varieties of apples. Site II (described above) was also used. Within each site, six nesting boxes were placed adjacent to the lupine plots and six others were placed $>600 \mathrm{~m}$ from the lupines, close to the reported upper foraging limit of several Osmia species (see Gathmann and Tscharntke 2002). Corrected bee release rates (as above) are summarized in Table 2. Following completion of activity, nests 
Table 2. Corrected rates of release (see the text for details) of bees in two commercially managed orchards (Aylesford, Wolfville) and one research orchard (site II) in 2004 and their proximity to established lupine plots.

\begin{tabular}{|c|c|c|c|c|c|c|}
\hline \multirow{2}{*}{$\begin{array}{l}\text { Nest } \\
\text { No. }\end{array}$} & \multicolumn{3}{|c|}{ Near lupine plots } & \multicolumn{3}{|c|}{$\begin{array}{c}\text { Farther }(\geq 600 \mathrm{~m}) \text { from lupine } \\
\text { plots }\end{array}$} \\
\hline & Aylesford & Wolfville & Site II & Aylesford & Wolfville & Site II \\
\hline 1 & 37 (93) & $40(94)$ & $45(87)$ & $48(86)$ & $48(92)$ & $45(94)$ \\
\hline 2 & $45(86)$ & $47(83)$ & $43(82)$ & $47(94)$ & $41(92)$ & $46(89)$ \\
\hline 3 & $46(102)$ & $44(81)$ & $42(70)$ & $47(90)$ & $44(86)$ & $44(95)$ \\
\hline 4 & $44(79)$ & $42(72)$ & $45(94)$ & $46(88)$ & $45(98)$ & $46(90)$ \\
\hline 5 & $44(100)$ & $43(78)$ & $45(83)$ & $43(78)$ & $47(85)$ & $45(95)$ \\
\hline 6 & $43(89)$ & $44(89)$ & $38(77)$ & $44(90)$ & $43(83)$ & $38(76)$ \\
\hline
\end{tabular}

Note: Values in parentheses are males.

were removed from the orchards and bees were left to develop to the pupal stage.

As an indirect measure of recovery, nesting tubes were removed from each nest following pupation and weighed (accuracy $0.1 \mathrm{~g}$ ). The nesting tubes were then cut longitudinally and the numbers of males and females per tube were determined. General Linearized Model (GLM) procedures (Minitab 2000) were used to look for differences in mass and number of bees recovered between sites and among nesting locations. Regression was also used to show the relationship between nesting-tube mass and the actual number of recovered bees to determine whether weighing the tubes could be used to accurately predict the number of bees produced.

\section{Results}

\section{Flowering phenology}

Flowering at site I began on 26 May in 2002 and 28 May in 2003. Peak flowering for both cultivars varied by 6 days between years, being later in 2003, and occurred 5 (2002) and 8 (2003) days after the commencement of flowering. By 5 June in 2002 and 10 June in 2003, petal drop was virtually complete for both cultivars (Fig. 2), although flowering within the orchard continued at low levels for several more days. In 2003, flowering of the cultivars at site II followed a similar pattern to that of the cultivars at site I, although 'NovaSpy' was a few days ahead of 'NovaMac' (Fig. 2).

On 31 May 2002, a few open lupine flowers were observed on the bottom portion of the racemes in the ditch adjacent to site I, slightly overlapping apple flowering; by 3 June many lupines were in bloom (approximately 10\%) and being foraged upon by $O$. lignaria (Fig. 2). The same trend was observed in 2003, with flowering lupines first observed on 1 June. The basic pattern of lupine flowering phenology is summarized in Figure 2. In both years, lupine flowering peaked within 2 weeks of peak apple flowering (estimated 25\%-75\% flowering; Fig. 2). Lupine flowering continued for almost 4 weeks, beyond the life-span of $O$. lignaria (Fig. 3). Lupine seed pods were observed by the third week of June in both years.

\section{Bee activity and recovery}

From the day of release, 16 May 2002, until the first count of nesting bees on 27 May 2002 (prior to a secondary release at site I; see Table 1), female numbers within nests at site I were lower than expected; of the females released, only $26.2 \pm 3.4 \%$ (mean $\pm \mathrm{SE}$ ) remained in the wooden nests and $43.5 \pm 7.6 \%$ in the $\mathrm{MC}$ nests (Fig. 3). A similar percentage of remaining females, $46.4 \pm 2.0 \%$, was observed in the MC nests at site II at the time of the first evening count in 2002 (Fig. 3). The number of females within the nests at both locations continued to decrease steadily in the weeks following flowering, with the exception of a slight increase at site I following the secondary release on 27 May 2002 (Fig. 3A). As a result, females were observed provisioning nests up to 54 days after the initial release at site I but not at site II.

Overall recovery of bees differed between the two sites. At site I an overall increase of $53.9 \%$ was observed in the wooden nests (data pooled across the three nests). Individual differences among the wooden nests were detected $\left(\chi_{0.05,2}^{2}=103.48\right)$ : the nest farthest from the lupines had the highest percent recovery (137\%), with each female producing, on average, 5.3 
Fig. 2. Flowering phenology of 'McIntosh' (Mac) and 'Cortland' (Cort) apple trees at site I in 2002 and 2003 and 'NovaMac' (NM) and 'NovaSpy' (NS) at site II in 2003, and the approximate flowering period for bigleaf lupine (Lupinus polyphyllus). The box shows the approximate "full bloom" phase (middle $25 \%-75 \%$ of racemes in flower), the arrow at the left shows early bloom (lower approximately $25 \%$ of raceme), the arrow at the right shows late bloom (upper approximately $25 \%$ of raceme in flower; lower approximately $25 \%$ with seed pods developing).

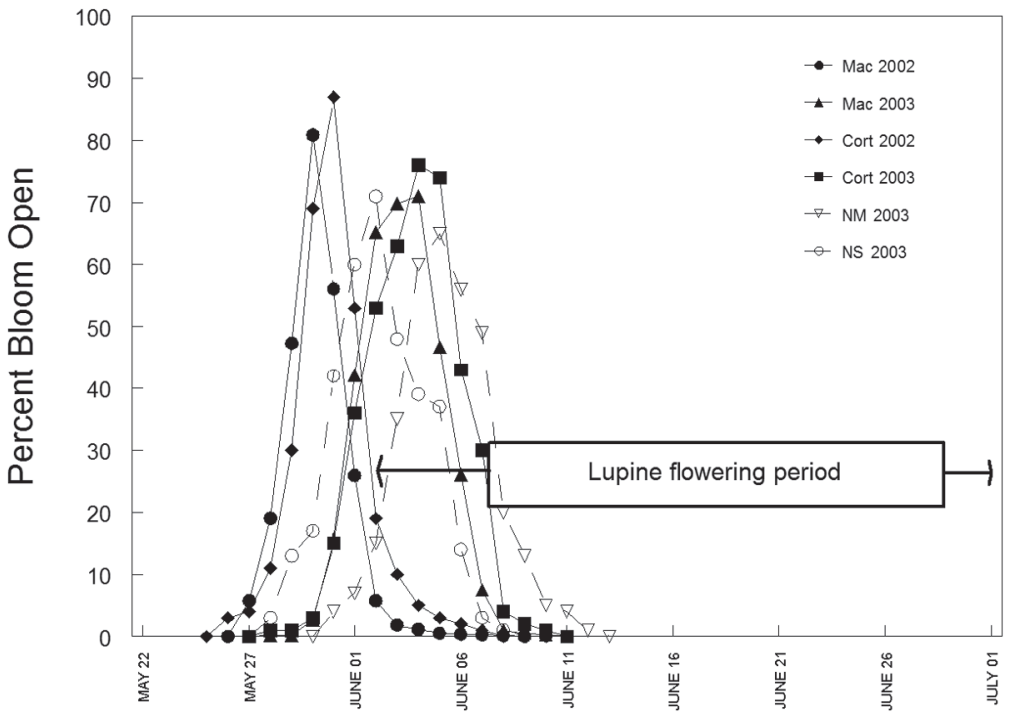

bees. The other two wooden nests had lower percent recovery and female fecundity $(27.8 \%$ near the lupines, 3.4 bees/female; $6.2 \%$ in the middle of the orchard, 3.3 bees/female). At site I the six MC nests performed significantly better ( $81.4 \%$ recovery) than the wooden nests. However, percent recovery varied among distances from the lupines $\left(\chi_{0.05,2}^{2}=199.95\right)$, with the greatest recovery observed at mid-distance (168.9\%, 6.6 bees/female) and farthest from the lupines $(126.9 \%, 7.5$ bees/female). The nests closest to the lupines failed to gain in population, with a loss of $32.2 \%$ and each female producing 2.5 bees.

Recovery was greatest in nests at site II: 1018 bees were produced, a pooled increase of $188 \%$ over the number released. Although recovery in all three nests at site II was $>120 \%$, differences were observed among distances $\left(\chi_{0.05,2}^{2}=37.33\right)$. The nest closest to the lupines produced the most bees, showing an increase of $263 \%$ (9.7 bees/female); recovery in the middistance nest was $177.4 \%$ ( 7.5 bees/female), and recovery in the nest farthest from the lupines was $121.6 \%$ ( 6.2 bees/female).

In 2003 the bees released were in poor condition (see above) and suffered $47.6 \%$ preemergence mortality in 2003 (versus 16.9\% in 2002). In addition, rainy weather through most of the apple flowering period prevented bee flight. Because of these factors, activity at the nesting sites was not evaluated in 2003. Percent recovery in 2003 was much lower than in 2002. At site I all nests had an overall decline in population, but differences in percent recovery were observed among the three distances from the lupine patch $\left(\chi_{0.05,2}^{2}=35.28\right)$. Recovery of released bees was $67.2 \%, 48.3 \%$, and $71.1 \%$ in nests nearest to the lupines, in the middle of the orchard, and farthest from the lupines, respectively. Similarly, females in nests closest to and farthest from the lupines produced a mean of 2.2 bees each, with much lower values observed in nests in the middle of the orchard (mean $=1.4$ bees/female $)$.

At site II an overall increase of $23.1 \%$ occurred, but percent recovery decreased as distance from the lupine patches increased $\left(\chi_{0.05,2}^{2}=14.75\right)$. Numbers of bees in nests closest to the lupine patch more than doubled (108.2\%, 7.2 bees/female), whereas those at mid-distance increased only slightly $(5.5 \%, 5.23$ bees/female). Although each female at the nests farthest from the lupines produced 4.4 bees, only $77.9 \%$ of the bees released were recovered. Percent recovery and activity at nests on the west side of the block were higher (based on observed 
Fig. 3. Numbers of nesting females (bars) and capped nesting tubes (symbols) observed in nests at site I in 2002. (A) Wooden nests; the arrow indicates the time of secondary release (see Table 1). (B) Milk-carton nests. (C) Relationship between milk-carton nests and number of days following release at site II. At site I, "near" nests were closest to the lupines; "mid" nests were $90 \mathrm{~m}$ from the lupines; and "far" nests were $180 \mathrm{~m}$ from the lupines. At site II,"mid" and "far" nests were approximately 35 and $70 \mathrm{~m}$ from the lupines, respectively. ; See Table 1 for release rates; initial release rates are corrected for mortality.

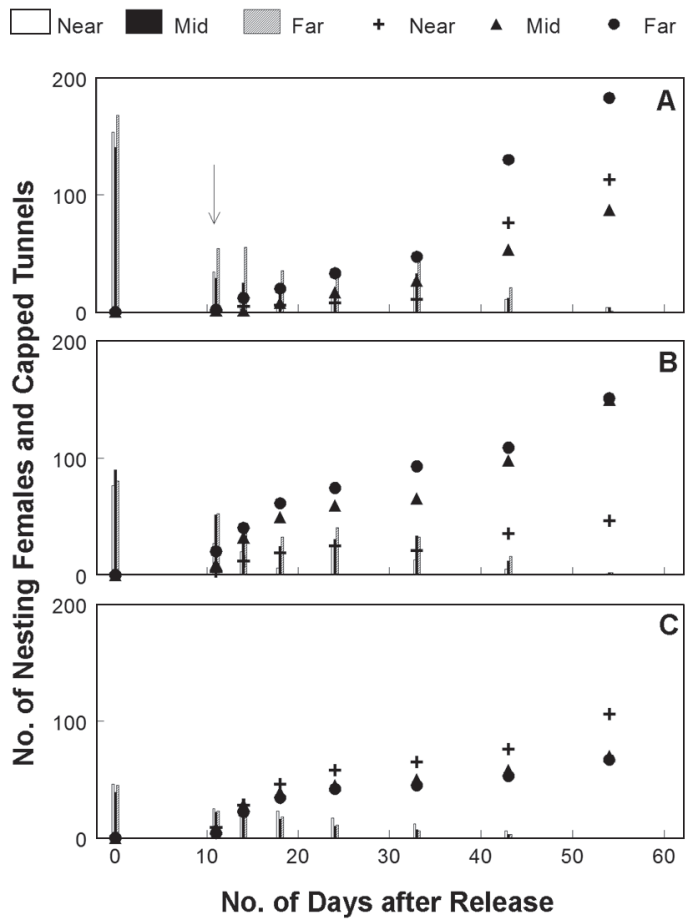

capped nesting tunnels) than at the respective distance-pair on the east side.

\section{Pollen use}

In 2002, prior to and during early apple bloom, garden yellowrocket, Barbarea vulgaris W.T. Aiton (Brassicaceae), constituted the largest proportion $(72.3 \%)$ of pollen collected at site I. Apple (7.9\%) and a species of dandelion, Taraxacum F.H. Wigg. (Asteraceae) (7.7\%), contributed similar amounts, and unknown pollen made up the remaining $12.1 \%$. During full to late bloom at site I, $76.1 \%$ of pollen collected was apple; lupine (11.0\%), dandelion $(2.1 \%)$, and several unidentified types of pollen were also collected. At site II, apple accounted for $93.6 \%$ of pollen collected, with pollen from cuckoo flower, Cardamine pratensis L. (Brassicaceae), making up most of the rest $(6.3 \%)$. Following apple flowering, lupine accounted for $98.0 \%$ and $93.2 \%$ of pollen at sites I and II, respectively, with dandelion being the next most abundant pollen at both sites. No differences in the proportion of lupine pollen collected with increase in distance from the plots were observed at site I $\left(F_{2,65}=1.43, P=0.259\right)$ or site II $\left(F_{2,25}=0.45, P=0.664\right)$.

As poor weather prevented bee flight during most of the apple flowering period in 2003 (see above), pollen was only sampled following crop flowering. Lupine accounted for $86.2 \%$ and $95.2 \%$ of pollen collected at sites I and II, respectively. Dandelion was the only other major pollen source $(>1 \%)$ at both sites. As in 2002, no differences in the proportion of lupine pollen collected with increase in distance from the plots were observed at site I $\left(F_{2,42}=0.13, P=\right.$ $0.88)$ or site II $\left(F_{2,26}=0.95, P=0.402\right)$.

\section{Commercial orchards}

Nests located adjacent to the lupines (164.9 \pm $16.2 \mathrm{~g}$ (mean $\pm \mathrm{SE}) ; n=18$ ) had significantly greater masses than those located farther away $(95.4 \pm 18.0 \mathrm{~g} ; n=18)\left(F_{1,32}=12.51, P=\right.$ $0.001)$. Significant differences in nest mass between orchards were observed $\left(F_{2,32}=9.82\right.$, $P<0.001$ ): nests in the research orchard (site II) $(80.31 \pm 18.8 \mathrm{~g} ; n=12)$ weighed less than those in the orchard in Aylesford (186.4 \pm $23.2 \mathrm{~g} ; n=12)$; nests in the orchard in Wolfville $(123.7 \pm 16.7 \mathrm{~g} ; n=12)$ were intermediate and did not differ from the other two orchards (Tukey's test, $P=0.05$ ).

Similarly, the number of bees produced per nest adjacent to the lupines (281.2 \pm 31.7 (mean $\pm \mathrm{SE}) ; n=18$ ) was significantly greater than the number produced farther from them $(125.4 \pm 33.5 ; n=18)\left(F_{1,32}=17.41, P<\right.$ $0.001)$. Percent recovery was therefore much greater adjacent to the lupines $(217.8 \pm 23.2 \%$ (mean $\pm \mathrm{SE}) ; n=18$ ) because nests at a distance showed a slight loss of bees relative to corrected release levels $(94.0 \pm 25.0 \% ; n=18)$. The same trend was observed among sites $\left(F_{2,32}=9.97, P<0.001\right)$, the research orchard (site II) having recovery rates $(96.9 \pm 31.7$ bees (mean $\pm \mathrm{SE}) ; n=12$ ) significantly lower than those observed in the orchard in Aylesford $(300.3 \pm 44.3$ bees; $n=12)$; the orchard in Wolfville ( $212.7 \pm 41.5$ bees; $n=12)$ was intermediate and did not differ from the other two orchards (Tukey's test, $P=0.05$ ). 
Fig. 4. Relationship between mass (g) of nesting tubes and number of bees contained in them.

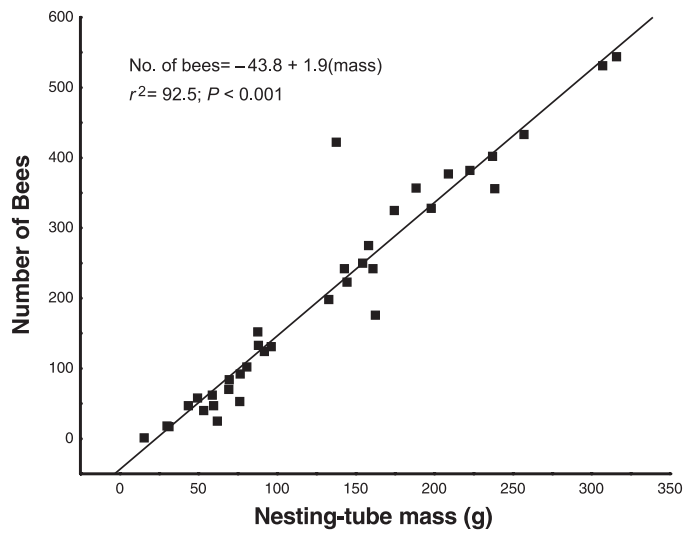

Nesting-tube mass was a reliable and laboursaving predictor of recovery $\left(r^{2}=92.5\right)$ (Fig. 4).

\section{Discussion}

Megachilid bees, particularly the genus Osmia, have great potential as crop pollinators (reviewed in Torchio 2003). Osmia lignaria, in particular, has been shown to be an exceptional pollinator of apple and several other rosaceous tree-fruit crops (Bosch and Kemp 1999; Torchio 2003). Pollen-use patterns in this study indicated that $O$. lignaria did contribute to apple pollination, as bees collected a high proportion of apple pollen (and see Sheffield 2006). Under commercial pollination conditions, this species has the potential for considerable population growth during the apple flowering period (Torchio 1984, 1985). For tree-fruit crops with a short flowering period ( $<2$ weeks), the fecundity of $O$. lignaria is probably maximized during this period of abundant pollen and nectar resources as long as weather conditions remain suitable for bee activity. However, Torchio (1985) reported that a reduction of fecundity may occur if excessive numbers of female $O$. lignaria are released within isolated orchards, and recommended release rates of approximately 100 females/ha.

Williams and Kremen (2007) demonstrated that fecundity of $O$. lignaria populations is significantly lower in managed sites when there is no connectivity to natural habitats with pollen sources. Following crop flowering, bees must search farther afield for other food plants, and overall fecundity can be reduced by the increase in time required to provision nests (Torchio 1985; Gathmann and Tscharntke
2002). Further reductions in population recovery may occur through dispersal of females to nesting sites closer to food-rich areas. Solitary bees typically forage within 120-600 m of their nests, the distance increasing with body size (Gathmann and Tscharntke 2002). Clearly, additional food sources must be provided to bees within crop systems when population recovery is desired if they are not readily available in the surrounding landscape.

Our trials in Nova Scotia suggest that noncrop food plants for pollinators like $O$. lignaria can be provided in areas adjacent to the target crop and within the flight distance of bees. Stands of lupine are easy to establish and maintain and are self-sustainable by seed set, and lupine pollen is collected in large amounts by O. lignaria. During this evaluation in 2001 (see Sheffield 2006) and 2002-2003, nesting activity (measured as nesting tube capping rate) continued to increase following apple bloom. This was an indirect indication that bees were finding sufficient food resources: the number of bees recovered at each site supported the trend indicated by nesting-tube capping. Unfortunately, mortality of released bees was high in 2003, most likely as a result of importation in January that year rather than at the recommended time, i.e., the previous autumn (Bosch and Kemp 2001). Aspects of wintering physiology in this species, including the problems associated with winter importation into Nova Scotia, are reviewed by Sheffield et al. (2008b).

Although both sites supported population increases in 2002 and 2003, differences in recovery between sites and among nests at each site were observed. Lupine patches were close enough to all nests used in this study $(<200 \mathrm{~m})$ to be utilized by $O$. lignaria, as indicated by population recovery and pollen use. At site I (2002), recovery at nests farthest from the lupine plot $(180 \mathrm{~m})$ was greater than at those closest to it. These results may be misleading because this orchard was also utilized for several small-scale (i.e., individual trees) insecticide trials at the south end of the orchard, close to the lupines. Although the impact of these pesticide trials on nesting bees was not directly quantified, bee activity was markedly lower following the spray treatments (C.S. Sheffield, pers. obs.). In contrast, bees in nests at site II (which received no insecticide treatments) maintained high activity, had higher percent recovery than bees at site I, and exhibited greatest percent recovery in nests closest to the lupines. 
Pesticide applications following flowering are required to manage pests that attack the developing fruit (MacHardy 2000), putting additional stress on nontarget arthropods within these systems. Although this was not evaluated in the larger study (Sheffield 2006), the observations reported here indicate that placing nests in agricultural landscapes is an important consideration in the management of non-Apis species. Relocation (as with honey bee colonies) of nesting females following crop flowering usually reduces recovery (Osgood 1974; Vicens and Bosch 2000; Sheffield 2006).

As pressures for increased pollination continue, developing methods that maximize pollinator fecundity to ensure pollination services in subsequent seasons is a priority. Overall, the apple-lupine combination appears to be a viable option for building populations of $O$. lignaria to meet orchard pollination needs in Nova Scotia. At all sites the flowering period of lupine began just as apple flowering was finishing, thus providing uninterrupted foraging opportunities for bees within these agro-ecosystems.

\section{Acknowledgements}

We thank Dr. Philip Torchio, formerly at the United States Department of Agriculture Bee Laboratory in Logan, Utah, for his advice and support during the initial stages of this study. We also thank Kim Jansen, Megan Hainstock, Derek Maske, and Darin Moran for assistance with experiment set-up and John Fitzpatrick for advice and efforts on nest construction. Thanks are extended to Doug Hennigar and Goeff Hennigar for establishing lupine plots in their orchards for our research, and the staff of Agriculture and Agri-Food Canada for their support. This study comprised part of the Ph.D. research of C.S. Sheffield and was funded by grants from the Agri-Focus 2000 Technology Development Program (Nova Scotia Department of Agriculture and Fisheries) and Agri-Futures Nova Scotia Association (Agriculture and AgriFood Canada) through the Nova Scotia Fruit Growers' Association.

\section{References}

Abel, C.A., and Wilson, R.L. 1998. The use of diverse plant species for increasing Osmia cornifrons (Hymenoptera: Megachilidae) in field cages. Journal of the Kansas Entomological Society, 71: 23-28.
Batra, S.W.T. 2001. Coaxing pollen bees to work for us. In Bees and crop pollination - crisis, crossroads, conservation. Edited by C.S. Stubbs and F.A. Drummond. Thomas Say Publications in Entomology: Proceedings, Entomological Society of America, Lanham, Maryland. pp. 85-93.

Bohart, G.E. 1972. Management of wild bees for the pollination of crops. Annual Review of Entomology, 17: 287-312.

Bosch, J., and Kemp, W.P. 1999. Exceptional cherry production in an orchard pollinated with blue orchard bees. Bee World, 80: 163-173.

Bosch, J., and Kemp, W.P. 2001. How to manage the blue orchard bee as an orchard pollinator. Sustainable Agriculture Network Handbook Series No. 5, Beltsville, Maryland.

Cox-Foster, D.L., Conlan, S., Holmes, E.C., Palacios, G., Evans, J.D., Moran, N.A., Quan, P.-L., Briese, T., Hornig, M., Geiser, D.M., Martinson, V., vanEngelsdorp, D., Kalkstein, A.L., Drysdale, A., Hui, J., Zhai, J., Cui, L., Hutchison, S.K., Simons, J.F., Egholm, M., Pettis, J.S., and Lipkin, W.I. 2007. A metagenomic survey of microbes in honey bee colony collapse disorder. Science (Washington, D.C.), 318: 283-287.

Dafni, A. 1992. Pollination ecology: a practical approach. Oxford University Press, New York.

DeGrandi-Hoffman, G. 1987. The honey bee pollination component of horticultural crop production systems. Horticultural Reviews, 9: 237-272.

DeGrandi-Hoffman, G. 2003. Honey bees in U.S. agriculture: past, present, and future. In For nonnative crops, whence pollinators of the future? Edited by K. Strickler and J.H. Cane. Thomas Say Publications in Entomology: Proceedings, Entomological Society of America, Lanham, Maryland. pp. 11-20.

Dunn, D.B., and Gillett, J.M. 1966. The lupines of Canada and Alaska. Canada Department of Agriculture Monograph No. 2.

Free, J.B. 1993. Insect pollination of crops. 2nd ed. Academic Press, San Diego, California.

Gathmann, A., and Tscharntke, T. 2002. Foraging ranges of solitary bees. Journal of Animal Ecology, 71: 757-764.

Kevan, P.G. 2003. Pollination for the 21st century: integrating pollinator and plant interdependencies. In For nonnative crops, whence pollinators of the future? Edited by K. Strickler and J.H. Cane. Thomas Say Publications in Entomology: Proceedings, Entomological Society of America, Lanham, Maryland. pp. 181-204.

Lindauer, M. 1967. Communication among social bees. Harvard University Press, Cambridge, Mass.

MacHardy, W.E. 2000. Current status of IPM in apple orchards. Crop Protection, 19: 801-806.

Michener, C.D. 2007. The bees of the world. 2nd ed. Johns Hopkins University Press, Baltimore, Md. 
Minitab. 2000. Minitab statistical software. Release 13 [computer program]. Pennsylvania State University, State College, Pennsylvania.

Osgood, C.E. 1974. Relocation of nesting populations of Megachile rotundata, an important pollinator of alfalfa. Journal of Applied Research, 13: $67-73$

Parker, F.D.S., Batra, S.W.T., and Tepidino, V.J. 1987. New pollinators for our crops. Agricultural Zoology Reviews, 2: 279-307.

Sheffield, C.S. 2006. Diversity and management of bees for the pollination of apple in the Annapolis Valley of Nova Scotia. Ph.D. thesis, University of Guelph, Guelph, Ont.

Sheffield, C.S., Kevan, P.G., Westby, S.M., and Smith, R.F. 2008a. Diversity of cavity-nesting bees (Hymenoptera: Apoidea) within apple orchards and wild habitats in the Annapolis Valley, Nova Scotia, Canada. The Canadian Entomologist, 140: 235-249.

Sheffield, C.S., Westby, S.M., Kevan, P.G., and Smith, R.F. $2008 b$. Winter management options for the orchard pollinator Osmia lignaria (Hymenoptera: Megachilidae) in Nova Scotia. Journal of the Entomological Society of Ontario, 139. In press.

Stephen, W.P. 1973. Insects as natural resources and tools of management. In Insects: studies in population management. Edited by P.W. Geier, L.R. Clark, D.J. Anderson, and H.A. Nix. Ecological Society of Australia Memoirs No. 1, Canberra, Australia. pp. 31-44.

Strickler, K., and Cane, J.H. (Editors). 2003. For nonnative crops, whence pollinators of the future? Thomas Say Publications in Entomology: Proceedings, Entomological Society of America, Lanham, Md.

Torchio, P.F. 1984. Field experiments with the pollinator species, Osmia lignaria propinqua
Cresson (Hymenoptera: Megachilidae) in apple orchards: III, 1977 studies. Journal of the Kansas Entomological Society, 57: 517-521.

Torchio, P.F. 1985. Field experiments with the pollinator species, Osmia lignaria propinqua Cresson, in apple orchards: V (1979-1980), methods of introducing bees, nesting success, seed counts, fruit yields (Hymenoptera: Megachilidae). Journal of the Kansas Entomological Society, 58: 448-464.

Torchio, P.F. 1990. Diversification of pollination strategies for U.S. crops. Environmental Entomology, 19: 1649-1656.

Torchio, P.F. 2003. Development of Osmia lignaria (Hymenoptera: Megachildae) as a managed pollinator of apple and almond crops: a case history. In For nonnative crops, whence pollinators of the future? Edited by K. Strickler and J.H. Cane. Thomas Say Publications in Entomology: Proceedings, Entomological Society of America, Lanham, Md. pp. 67-84.

Vicens, N., and Bosch, J. 2000. Nest site orientation and relocation of populations of the orchard pollinator Osmia cornuta (Hymenoptera: Megachilidae). Environmental Entomology, 29: 69-75.

von Frisch, K. 1967. The dance language and orientation of bees. Harvard University Press, Cambridge, Mass.

Williams, N.M. and Kremen, C. 2007. Resource distributions among habitats determine solitary bee offspring production in a mosaic landscape. Ecological Applications, 17: 910-921.

Zar, J.H. 1999. Biostatistical analysis. 4th ed. Prentice Hall, Upper Saddle River, N.J.

Zinck, M. 1998. Roland's flora of Nova Scotia. Nimbus Publishing and the Nova Scotia Museum, Halifax, N.S. 